відчуває страх перед невідомим, а зацікавити його, насамперед для того, щоб утримати його увагу якнайдовше.

\title{
Література
}

1. Бацевич Ф. С. Основи комунікативної лінгвістики : [підручник] / Ф. С. Бацевич. [2-е вид., доп.]. - Київ : ВЦ «Академія», 2009. - 376 с. 2. Володина Л. В. Деловое общение и основы теории коммуникации : [учеб.-метод. пособие] / Л. В. Володина, О. К. Карпухина. Санкт-Петербург : СПбГУТ, 2002. - 56 с. 3. Давыдова И. П. Педагогам о дистанционном обучении : [методическое пособие] / И. П. Давыдова, М. Б. Лебедева, И. Б. Мылова и др. [под ред. Т. В. Лазыкиной]. - Санкт Петербург : РЦОКОиИТ, 2009. - 98 с. 4. Мылова И. Б. Инновации в образовании: дистанционное обучение: [методическое пособие] / И. Б. Мылова, $\quad$ В. Л. Матвеев, $\quad$ А. И. Мочкина, $\quad$ Т. М. Прокофьева. - Санкт-Петербург : СПбАППО, 2009. - 119 с. 5. Николаева Ж. В. Основы теории коммуникации : [учеб.-метод. пособие для студентов спец. 350400 «Связи с общественностью»] / Ж. В. Николаева. - УланУдэ : ВСГТУ, 2004. - 274 с. 6. Ребрина Ф. Г. Этапы разработки электронного учебного курса на платформе LMS Moodle / Ф. Г. Ребрина, И. А. Леонтьева // Вестник Челябинского государственного педагогического университета. - 2014. - № 2. - С. 204-213. 7. Саитова А. С. Рекомендации по созданию курса, предназначенного для размещения на сайте дистанционного обучения [Электронный ресурс] / А. С. Саитова. - ТГСПА им. Д. И. Менделеева. - Режим доступу : http://distance.tgspa.ru/file.php/1/rekomendacii/ Rekomendaci_po_sozdaniy_kursa.pdf.

УДК 371.333+371.13+37.018.46

Людмила Калачова

\section{ПЕДАГОГІЧНА ТЕХНОЛОГІЯ ПІДГОТОВКИ ВИКЛАДАЧІВ ІНСТИТУТІВ ПІСЛЯДИПЛОМНОЇ ПЕДАГОГІЧНОЇ ОСВІТИ ДО ЗАСТОСУВАННЯ АУДІОВІЗУАЛЬНИХ ЗАСОБІВ НАВЧАННЯ}

Калачова Л. В. Педагогічна технологія підготовки викладачів інститутів післядипломної педагогічної освіти до застосування аудіовізуальних засобів навчання.

У статті описано компоненти педагогічної технології підготовки викладачів інститутів післядипломної педагогічної освіти до застосування аудіовізуальних засобів навчання: організаційно-діагностичний, змістово-процесуальний та аналітико-рефлексивний.

Ключові слова: аудіовізуальні засоби навчання, післядипломна педагогічна освіта, педагогічна технологія, компоненти педагогічної технології.

Калачёва Л. В. Педагогическая технология подготовки преподавателей институтов последипломного педагогического образования $\mathrm{K}$ применению аудиовизуальных средств обучения.

В статье описаны компоненты педагогической технологии подготовки преподавателей институтов последипломного педагогического образования к применению аудиовизуальных средств обучения: организационно-диагностический, содержательнопроцессуальный и аналитико-рефлексивный.

Ключевые слова: аудиовизуальные средства обучения, последипломное педагогическое образование, педагогическая технология, компоненты педагогической технологии.

Kalachova L. V. Technology of postgraduate education teachers' training to the use of 
audio-visual teaching aids.

The article describes the components of technology of postgraduate education teachers' training to the use of audio-visual teaching aids: organizational diagnosis, procedure and content, analytical and reflective.

Key words: audio-visual training aids, postgraduate education, educational technology, components of educational technology.

Технології розвиваються із новими відкриттями в галузі науки та техніки, що впливає на всі сфери життя суспільства, зокрема й науку та освіту. Відповідно виникає необхідність розроблення і нових педагогічних технологій, які б відповідали вимогам часу та рівню розвитку сучасного суспільства в науковому та технологічному аспектах. Лабораторія систем відкритої освіти Науково-дослідного інституту ДВНЗ «Університет менеджменту освіти» НАПН України працює в рамках планової держбюджетної науково-дослідної роботи за темою «Теоретико-методичні засади проектування технологій навчання в системі відкритої післядипломної педагогічної освіти» й однією із технологій, які розробляються для апробації теоретичних досліджень, $є$ технологія підготовки викладачів інститутів післядипломної педагогічної освіти (ІППО) до застосування аудіовізуальних засобів навчання.

Дослідженню питання педагогічної технології, критеріям, що її визначають, ключовим особливостям її розроблення та структурним складникам педагогічних технологій присвячені роботи таких науковців, як: В. Беспалько, Т. Колбіна, І. Коновальчук, В. Кукушина, I. Прокопенко, О. Сакієв, Г. Селевко, М. Сибірська, С. Сисоєва, Л. Сігаєва, Є. Совєтова, Е. Федорчук та ін.

Мета статmі: обгрунтувати педагогічну технологію підготовки викладачів ІППО до застосування аудіовізуальних засобів навчання.

Розглядаючи технологію підготовки викладача ІППО до використання аудіовізуальних засобів навчання, звернемося до моделі технології підготовки вчителя до інноваційної діяльності, запропонованої у дисертаційній роботі О. Козловою, яка складається із трьох компонентів: змістового, процесуального, результативно-оцінного. Змістовий компонент відповідає за готовність вчителя до нової діяльності, наявність комунікативної та рефлексивної культури, системне бачення педагогічної діяльності в різноманітті окремих педагогічних ситуацій. Процесуальний компонент описує етапи підготовки вчителя, зокрема: організаційнодіагностичний, навчально-регулятивний, корекційно-діяльнісний, аналітико-рефлексивний. До результативно-оцінного компонента належать показники сформованості до інноваційної діяльності: мотивація, технолого-педагогічна готовність, ставлення до своєї професійної діяльності [3].

У структурі педагогічної технології С. Сисоєва виокремлює такі компоненти [4, с. 74]: концептуальний, який відображає «ідеологію» проектування і впровадження педагогічної технології; змістово-процесуальний, який відображає мету (загальну і конкретні цілі); зміст навчального матеріалу, методи і форми його функціонування в освітньому процесі, методи і форми навчання, виховання, розвитку учнів; методи і форми педагогічної діяльності вчителя; діяльність учителя з управління навчально-виховним процесом; професійно-педагогічний компонент, який відображає залежність успішності функціонування і відтворення спроектованої педагогічної технології від рівня педагогічної майстерності вчителя.

Для загальної характеристики педагогічних технологій часто використовують спрощену структуру, яка включає такі елементи [5, с. 34]: мета; концептуальна частина (філософські та психолого-педагогічні ідеї); змістова частина (особливості змісту освіти); 
процесуальна (етапи педагогічного процесу, форми, методи, прийоми і засоби діяльності учасників педагогічного процесу).

Відповідно до вищезазначених компонентів проектування педагогічних технологій, спроектуємо технологію підготовки викладачів ІППО до застосування аудіовізуальних засобів навчання.

Перший компонент - організаційно-діагностичний, він передбачає: проведення ознайомчих семінарів з питань можливостей використання аудіовізуальних засобів в освіті, роз'яснень щодо підвищення ефективності сприйняття навчальних матеріалів з використанням таких засобів; проведення анкетувань, бесід, спостережень для з'ясування освітніх потреб викладачів інститутів післядипломної освіти та наявного рівня компетентності в питаннях використання аудіовізуальних засобів навчання, рівня готовності викладачів до впровадження аудіовізуальних засобів навчання у свою професійну діяльність; розроблення необхідної організаційної документації (робоча програма, навчально-тематичний план, база тестових, індивідуальних та практичних завдань); підготовку необхідних засобів навчання.

На організаційно-діагностичному етапі ми остаточно формуємо уявлення про особливості контингенту майбутніх учасників підготовки. Цільова аудиторія педагогічної технології - викладачі ІППО. Провідна особливість контингенту тих, для кого буде застосована педагогічна технологія, - необхідність дотримання андрагогічних принципів. Мета підготовки: надати теоретичні знання 3 питань можливостей використання аудіовізуальних засобів навчання та основ візуального сприйняття інформації педагогічними працівниками інститутів післядипломної педагогічної освіти, сформувати вміння та навички використання сучасних аудіовізуальних засобів навчання (відеофрагментів, вебінарів) 3 можливістю їх створення, редагування та подальшого розміщення на базі веб-середовищ освітніх закладів, таким чином сформувавши компетентність викладача ІППО в галузі використання аудіовізуальних засобів навчання; спонукати потребу у викладачів ІППО до постійного саморозвитку та використання інновацій у своїй педагогічній діяльності для підвищення ії ефективності; забезпечити високий рівень готовності викладачів ІППО до використання аудіовізуальних засобів навчання у професійній діяльності.

В основу підготовки покладено такі підходи: компетентнісний (ключові компетенції педагога - це комплекс знань, умінь, практичних та пізнавальних навичок особистості, його мотивації, емоцій та ставлення до конкретної діяльності, ціннісні та етичні регулятиви), діяльнісний (набуття необхідних компетенцій відбувається у процесі активної діяльності), особистісно-орієнтований (опора на особисті якості тих, хто навчається, їх потреби та потенціал), екзистенційний (усвідомлення відповідальності за власний вибір, висока внутрішня мотивація, прагнення до саморозвитку, робота над подоланням психологічних бар’єрів), синергетичний (узгодження взаємодії між учасниками спільної діяльності, саморозвиток на основі рефлексії) підходи.

Змістово-процесуальний компонент відображає безпосередньо навчальну діяльність, реалізацію розробленої програми підготовки. Ключовим елементом цього компонента є зміст навчального матеріалу та форми, методи, засоби навчання. Найголовніша мета навчальної діяльності - надати викладачам необхідні знання, вміння та навички для можливості використання аудіовізуальних засобів навчання у педагогічній діяльності, сформувати творчу активність педагогів.

Загалом підготовка викладачів ІППО розрахована на 144 години (4 кредити). Проте у процесі апробації використовувались різні форми навчання, і в зв'язку з цим у деяких експериментальних закладах була застосована скорочена програма навчання обсягом 54 
години (1,5 кредити). Зміст навчальних матеріалів підготовки розкрито у трьох модулях. Електронний навчальний курс для супроводу процесу навчання скадається з 3 модулів, які містять 9 змістових модулів.

Модуль 1 «Теоретичні аспекти створення і застосування аудіовізуальних засобів навчання» містить 3 змістові модулі: 1) Поняття аудіовізуальних засобів навчання, їх класифікація (розкривається принцип наочності у навчанні загалом та в підвищенні кваліфікації зокрема; розглядаються поняття засобів навчання; основи сприйняття інформації; класифікація аудіовізуальних засобів навчання та їх короткий опис); 2) Методика використання аудіовізуального матеріалу (подаються методичні рекомендації щодо застосування аудіовізуальних засобів навчання у процесі навчання, підвищення кваліфікації);

3) Психолого-педагогічні вимоги до створення та застосування аудіовізуального матеріалу (розкриваються питання дотримання психолого-педагогічних вимог при створенні аудіовізуального матеріалу). Модуль 2 «Використання прикладного програмного забезпечення для створення відеофрагментів» включає 3 змістові модулі: 1) Підготовка до створення відеоматеріалу (описано попередню необхідну базову підготовку матеріалу для подальшого створення відеофрагменту); 2) Практичний блок. Створення відеофрагментів (розміщені завдання, виконуючи які, учасник курсу отримує практичні навички створення відеофрагментів); 3) Відеоматеріали у глобальній мережі Internet (висвітлені питання пошуку відеоматеріалів у глобальній мережі Інтернет; можливі варіанти завантаження потрібних відеофрагментів на власний комп’ютер та способи розміщення напрацювань учасників курсу в мережі Інтернет). Модуль 3 «Методика організації та проведення вебінарів» містить 3 змістові модулі: 1) Підготовка до проведення вебінару (організаційні та технічні питання; необхідні програмні, матеріальні ресурси; умови проведення та результативної співпраці у вебінарі); 2) Ознайомлення 3 платформами для проведення вебінарів (питання оптимального вибору платформи для проведення вебінару; цінова політика комерційних послуг); 3) Контрольноузагальнюючий модуль.

Для підготовки викладача до використання аудіовізуальних засобів навчання 3 урахуванням специфіки роботи викладачів та необхідністю безвідривності від навчального навантаження протягом навчального року може бути запропоновано 3 форми навчання: очна, очно-дистанційна та дистанційна. Учасникам підготовки пропонується обрати найбільш оптимальну форму взаємодії з викладачем та іншими учасниками підготовки залежно від базового рівня підготовки та особливостей індивідуального темпу навчання, наявних засобів навчання та графіка робочого навантаження.

Методичне забезпечення процесу підготовки викладачів до використання аудіовізуальних засобів навчання містить: методичні рекомендації «Методика підготовки дидактичного матеріалу з використанням аудіовізуальних засобів навчання в системі підвищення кваліфікації педагогічних працівників» у друкованому та електронному форматах (на CD-диску та у форматі електронного курсу) [1; 2]. Електронне навчально-методичне забезпечення підготовки викладачів містить презентації, схеми, діаграми, відеоінструкції із виконання практичних завдань, відеозаписи вебінарів, відеолекції, що унаочнить процес підвищення кваліфікації та зробить його більш ефективним. Крім того, методичне забезпечення містить інструкції та алгоритми для виконання практичних, індивідуальних робіт, такі, що пояснюють роботу програмного забезпечення або окремих елементів електронного навчального курсу. До кожного модуля у процесі підготовки викладачів розроблено тестові завдання (форми тестових завдань: вибір правильної відповіді (або кількох); встановлення відповідності, встановлення правильної послідовності), які готують 
слухачів до підсумкового тестування в кінці курсу підготовки.

Методи навчання в процесі підготовки: мотивація, стимулювання, корекція та самокорекція, рефлексія, дискусії, пошукові та творчі завдання, проектна діяльність (розроблення власних засобів навчання).

Методи перевірки знань: письмові відповіді на питання для самоконтролю та самоперевірки, поточне та підсумкове тестування, виконання практичних та індивідуальних робіт, складання алгоритмів, аналіз та самоаналіз за алгоритмами.

У ході підготовки використані індивідуальні форми навчання (виконання індивідуальних завдань), мікрогрупові (для роботи над практичними завданнями, виконання проектної діяльності) та групові форми навчання.

Основними формами роботи під час підготовки викладачів до використання аудіовізуальних засобів навчання $є$ : самостійна робота за комп’ютером; виконання індивідуальних завдань; робота в парах та групах; колективне обговорення сучасних проблем, що стосуються впровадження інформаційно-комунікаційних технологій у навчальний процес (в тому числі у форумах); інтерактивні методи навчання; використання програмного забезпечення для створення відеофрагментів; створення презентації, відеоматеріалів (запис подій з екрану; відеозвернення; оперативна зйомка) для власного дистанційного курсу; аналіз створених відеофрагментів на відповідність психолого-педагогічним та санітарним вимогам за заданими критеріями; робота у вебінарах з використанням різного програмного та апаратного забезпечення; робота в дистанційному курсі.

Самостійна робота учасників програми підготовки спрямована на відпрацювання навичок роботи з аудіовізуальними матеріалами, розширення свого кругозору в питаннях можливостей використання таких засобів навчання у своїй професійній діяльності, підбір найбільш зручного програмного забезпечення для роботи з урахуванням індивідуальних особливостей. Для самостійної роботи запропоновані такі завдання та проблемні питання: ознайомлення із ресурсами мережі Інтернет відповідно до класифікації аудіовізуальних засобів навчання за поданими гіперпосиланнями (студентське телебачення, відеолекції тощо); ознайомлення 3 організацією подкастів; побудова власної моделі використання аудіовізуальних засобів навчання у своїй професійній діяльності; ознайомлення 3 різноманітним програмним забезпеченням для створення відеозаписів та їх редагування, індивідуальний підбір зручної та функціональної програми; ознайомлення 3 програмним забезпеченням для відпрацювання навичок підбору кольорів у поданні візуального матеріалу (кольорові калькулятори); встановлення на власний комп’ютер спеціального прикладного забезпечення для завантаження відео $з$ мережі Інтернет; ознайомлення 3 їх інтерфейсом та можливостями; розроблення індивідуального сценарію підготовки до проведення вебінару та його подальшого опрацювання; ознайомлення з різними платформами для проведення вебінарів, їх порівняння.

Індивідуальні завдання для учасників семінару спрямовані на практичне застосування отриманих під час навчання знань у своїй професійній діяльності. Учасники семінару повинні власноруч створити 2 відеофрагменти за тематикою своєї наукової або викладацької діяльності (враховуючи їх самостійне редагування та оформлення): один на основі оперативної зйомки, другий на основі зйомки подій з екрану, а також провести невеликий за тривалістю фрагмент вебінару з використанням основних функціональних можливостей обраної платформи.

Технічне забезпечення, необхідне для участі у програмі підготовки, передбачає персональний комп’ютер, веб- або відеокамеру, навушники або колонки, мікрофон. Для виконання програми підготовки викладачів ІППО до застосування аудіовізуальних засобів 
навчання необхідне програмне забезпечення для запису відео, Flash Player (не нижче 9 версії), стандартні додатки MS Office, середовище дистанційного навчання Moodle.

Спілкування між учасниками семінару, куратором-тьютором та учасниками семінару відбувається засобами чатів, електронної пошти, форумів, сервісів відеозв'язку, вебінарів.

Для отримання сертифікату про проходження семінару кожен з учасників повинен виконати 80-100\% поставлених завдань, надати хоча б один заліковий відеофрагмент (із 2 необхідних) та взяти участь у проведенні вебінару.

Аналітико-рефлексивний компонент допомагає проаналізувати ступінь досягнення поставленої початкової мети підготовки та визначити причини, які могли викликати невідповідність поставлених цілей та результатів підготовки.

Засоби діагностики успішності навчання: відповіді на запитання для самоконтролю; обговорення теоретичного матеріалу у форумах; виконання практичних та індивідуальних робіт; аналіз виконаних колегами робіт; тестування; вихідне анкетування.

На цьому етапі ми аналізуємо результати навчальної діяльності - готовність викладачів до використання аудіовізуальних засобів навчання відповідно до рівнів та критеріїв сформованості готовності. За результатами аналізу необхідно встановити помилки та неточності у процесі підготовки, з'ясувати найбільш ефективні методи та засоби навчання, доопрацювати зміст навчального матеріалу, вдосконалити форми роботи слухачів. 3 цією метою після здійснення підготовки викладачів іï учасники повинні заповнити анкету, результати якої розкриватимуть труднощі, з якими вони зіштовхнулися (у технічному i психологічному планах), необхідність отриманих у курсі знань у практичній діяльності та інші питання, пов’язані із застосуванням аудіовізуальних засобів навчання.

Відповідно до проаналізованої літератури у процесі проектування педагогічної технології підготовки викладачів ІППО до застосування аудіовізуальних засобів навчання ми визначили такі компоненти: організаційно-діагностичний (з'ясування освітніх потреб, мотивів до навчальної діяльності та базового рівня IКТ-компетентності учасників процесу підготовки; визначення цілей навчання, основних концептуальних засад підготовки тощо), власне навчальна діяльність (зміст та форми навчання, методичне забезпечення навчальної діяльності, визначення методів та засобів навчання та перевірки знань, технічне та програмне забезпечення тощо) та аналітико-рефлексивний (результати навчання, діагностика результатів, виявлення недоліків технології та їх ліквідація). Перспективи подальших розвідок у межах окресленої проблеми вбачаємо у формулюванні загальних рекомендацій щодо проектування та розроблення педагогічних технологій у системі відкритої післядипломної педагогічної освіти.

\section{Література}

1. Блажко Л. В. Методика підготовки дидактичного матеріалу 3 використанням аудіовізуальних засобів навчання : [метод. реком.] / Л. В. Блажко, Л. Л. Ляхоцька. - Київ : Вид-во УМО, 2011. - 48 с. 2. Калачова Л. В. Електронний навчальний курс «Підготовка викладачів інститутів післядипломної педагогічної освіти до застосування аудіовізуальних засобів навчання» [Електронний ресурс]. - Режим доступу: http://avzn.distance.in.ua. 3. Козлова О. Г. Підготовка вчителя до інноваційної діяльності в системі післядипломної освіти: дис. на здобуття наук. ступеня канд. пед. наук : 13.00.01/ Козлова Олена Григорівна. - Київ, 1999. - 235 с. 4. Сисоєва С. О. Інтерактивні технології навчання дорослих : [навч.-метод. посіб.] / С. О. Сисоєва. - Київ : ВД «ЕКМО», 2011. - 324 с. 5. Федорчук Е. I. Сучасні педагогічні технології : [навч.-метод. посіб.] / Е. І. Федорчук. Кам’янець-Подільський : Абетка, 2006. - 212 с. 